\title{
Pengaruh Gaya Kepemimpinan, Motivasi Dan Disiplin Kerja Terhadap Kinerja Karyawan (Studi Kasus PT. Modernland Realty, TBK)
}

\author{
${ }^{1}$ Aidil Amin Effendy, ${ }^{2}$ Juwita Ramadani Fitria \\ Dosen Fakultas Ekonomi Universitas Pamulang \\ Email :1 $\underline{\text { dosen00967@unpam.ac.id }}$
}

\begin{abstract}
ABSTRAK
Tujuan dari penelitian ini adalah untuk mengetahui pengaruh gaya kepemimpinan terhadap kinerja karyawan, motivasi terhadap kinerja karyawan, disiplin kerja terhadap kinerja karyawan dan pengaruh gaya kepemimpinan, motivasi dan disiplin kerja secara simultan terhadap kinerja karyawan PT Modernland Realty Tbk. Metode penelitian yang dipergunakan dalam penelitian ini adalah metode assosiatif kuantitatif dan pengumpulan data dengan observasi dan penyebaran kuesioner. Sampel dalam penelitian ini sebanyak 130 orang karyawan. Metode analisis data dengan "Uji validitas, uji reliabilitas, uji asumsi klasik, persamaan regresi linier berganda, koefisien korelasi, koefisien determinasi dan pengujian hipotesis." Hasil penelitian menunjukkan korelasi berganda sebesar $\mathrm{r}=$ 0, 679 yang berarti hubungan antara gaya kepemimpinan, motivasi dan disiplin kerja secara simultan terhadap kinerja karyawan berada pada kategori kuat. Nilai koefisien determinasi (KD) tersebut diperoleh sebesar 46,2\%. Hal ini menunjukan bahwa besarnya kontribusi ketiga variabel bebas terhadap variabel terikat sebesar 46,2\%, sedangkan selebihnya 53,8\% dipengaruhi faktor-faktor lain. Adapun hasil uji $\mathrm{F}$ dapat diperoleh nilai $\mathrm{f}_{\text {hitung }}>\mathrm{f}_{\text {tabel }}$ yaitu 36.018> 2,68 dan nilai sig $0,000<$ 0,005. "Maka, gaya kepemimpinan, motivasi dan disiplin kerja secara simultan terhadap kinerja karyawan pada PT. Modernland Realty Tbk"
\end{abstract}

\section{Kata Kunci : Gaya Kepemimpinan, Motivasi, Disiplin Kerja dan Kinerja Karyawan}




\section{PENDAHULUAN}

Pada berbagai bidang khususnya kehidupan berorganisasi, faktor manusia merupakan masalah utama disetiap kegiatan yang ada di dalamnya. Organisasi merupakan "Kesatuan sosial yang dikoordinasikan secara sadar dengan sebuah batasan yang reaktif dapat diidentifikasikan, bekerja secara terus menerus untuk mencapai tujuan" (Robbins, 2013). Semua tindakan yang diambil dalam setiap kegiatan diprakarsai dan ditentukan oleh manusia yang menjadi anggota perusahaan. Perusahaan membutuhkan adanya faktor sumber daya manusia yang potensial baik pemimpin maupun karyawan pada pola tugas dan pengawasan yang merupakan penentu tercapainya tujuan perusahaan.

Sumber daya manusia merupakan tokoh sentral dalam organisasi maupun perusahaan agar aktivitas manajemen berjalan dengan baik, perusahaan harus memiliki karyawan yang berpengetahuan dan berketrampilan tinggi serta usaha untuk mengelola perusahaan seoptimal mungkin sehingga kinerja karyawan meningkat. Menurut Effendy, A.A. (2018), bahwa kinerja adalah "Hasil kerja yang dapat dicapai oleh seseorang atau sekelompok orang dalam suatu organisasi, yang dimulai dari proses awal sampai akhir sebagai hasil yang didapat."

Organisasi yang baik adalah organisasi yang berusaha meningkatkan kemampuan sumber daya manusianya, karena hal tersebut merupakan faktor kunci untuk meningkatkan kinerja karyawan. Peningkatan kinerja karyawan akan membawa kemajuan bagi perusahaan untuk dapat bertahan dalam suatu persaingan lingkungan bisnis yang tidak stabil. Oleh karena itu upayaupaya untuk meningkatkan kinerja karyawan merupakan tantangan manajemen yang paling serius karena keberhasilan untuk mencapai tujuan dan kelangsungan hidup perusahaan tergantung pada kualitas kinerja sumber daya manusia.

Penelitian ini mengambil obyek penelitian pada PT. Modernland Realty yang merupakan perusahaan bergerak di bidang jasa property rumah. Kegiatan yang dilakukan PT. Modernland Realty adalah membangun rumah. Kinerja karyawan yang tinggi sangatlah diharapkan oleh perusahaan terserbut. Semakin banyak karyawan yang mempunyai kinerja tinggi, maka produktivitas perusahaan secara keseluruhan akan meningkat sehingga perusahaan akan memenangi persaingan.

Karyawan dituntut untuk mampu menyelesaikan tugas dan tanggung jawabnya secara efektif dan efisien keberhasilan karyawan dapat diukur melalui kepuasan konsumen, berkurangnya jumlah keluhan dan tercapainya target yang optimal kinerja karyawan PT. Modernland Realty juga dapat diukur melalui penyelesaian tugasnya secara efektif dan efsien serta melakukan peran dan fungsinya demi keberhasilan suatu perusahaan. 
Terdapat faktor negatif yang dapat menurunkan kinerja karyawan, diantaranya adalah menurunnya keinginan karyawan untuk mencapai prestasi kerja, kurangnya ketepatan waktu dalam penyelesaian pekerjaan sehingga kurang menaati peraturan, pengaruh yang berasal dari lingkungannya, teman sekerja yang juga menurun semangatnya dan tidak adanya contoh yang harus dijadikan acuan dalam pencapaian prestasi kerja yang baik. Semua itu merupakan sebab menurunya kinerja karyawan dalam bekerja. Faktor-faktor yang dapat digunakan untuk meningkatkan kinerja diantaranya adalah gaya kepemimpinan, motivasi dan disiplin kerja.

"Gaya kepemimpinan yang tepat akan menimbulkan motivasi seseorang untuk berprestasi. Sukses tidaknya karyawandalam prestasi kerja dapat dipengaruhi oleh gaya kepemimpinan atasannya" (Hardini, 2001 dalam Suranta, 2002). Suranta (2002) dan Tampubolon (2007) telah meneliti bahwa "Pengaruh gaya kepemimpinan terhadap kinerja, menyatakan bahwa gaya kepemimpinan mempunyai pengaruh yang signifikan terhadap kinerja karyawan."

Motivasi adalah "Dorongan, upaya dan keinginan yang ada di dalam diri manusia yang mengaktifkan, memberi daya serta mengarahkan perilaku untuk melaksanakan tugas-tugas dengan baik dalam lingkup pekerjaannya". Hakim, 2006). Robbins (2013) mendefinisikan "Motivasi sebagai proses yang ikut menentukan intensitas, arah, dan ketekunan individu dalam usaha mencapai sasaran."

Menurut Budi Setiyawan dan Waridin (2006) "Disiplin sebagai keadaan ideal dalam mendukung pelaksanaan tugas sesuai aturan dalam rangka mendukung optimalisasi kerja." Salah satu syarat agar disiplin dapat ditumbuhkan dalam lingkungan kerja ialah, adanya pembagian kerja yang tuntas sampai kepada pegawai atau petugas yang paling bawah, sehingga setiap orang tahu dengan sadar apa tugasnya, bagaimana melakukannya, kapan pekerjaan dimulai dan selesai, seperti apa hasil kerja yang disyaratkan, dan kepada siapa mempertanggung jawabkannya.

Berdasarkan survei pendahuluan, peneliti menemukan adanya kekurang menaati tata tertib, ketentuan-ketentuan perusahaan yang memberatkan karyawan, disamping gaya kepemimpinan dan motivasi yang cukup tinggi. Kemudian timbul pemikiran bagaimana keseluruhan faktor tersebut saling berkesinambungan sehingga mempengaruhi kinerja karyawan.

Berdasarkan uraian diatas maka perlu dilakukan penelitian dengan judul: "Pengaruh Gaya Kepemimpinan, Motivasi dan Disiplin Kerja terhadap Kinerja Karyawan PT Modernland Realty Tbk".

Dari uraian pemikiran tersebut diatas dapat diperjelas melalui variabel pengaruhgaya kepemimpinan, motivasi dan disiplin kerja terhadap kinerja karyawan, secaraskematis 
digambarkan seperti pada gambar dibawah ini:

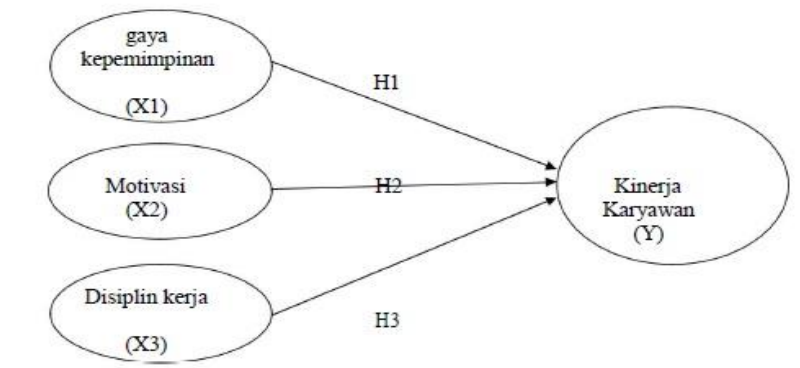

Sumber: konsep yang dikembangkan dalam penelitian ini.

\section{Gambar 1 : Kerangka Pemikiran}

\section{METODE PENELITIAN}

Jenis penelitian merupakan penelitian kuantitatif karena data penelitian berupa angka-angka yang nantinya akan dianalisis menggunakan statistik Penelitian ini bertujuan untuk mengetahui pengaruh Lingkungan Kerja, dan Stres Kerja Terhadap Kinerja Karyawan pada PT. Modernland Realty, Tbk

\section{A. Definisi Operasional Variabel}

Definisi operasional yang digunakan dalam penelitian ini kemudian diuraikan menjadi indikator empiris yang meliputi:

1. Kinerja karyawan

Menurut Mangkunegara dalam Sunarsi, D. (2019) kinerja merupakan "Hasil kerja secara kualitas dan kuantitas yang dicapai oleh seseorang dalam melaksanakan fungsinya sesuai dengan tanggungjawab yang diberikan kepadanya." Beberapa indikator untuk mengukur sejauh mana pegawai mencapai suatu kinerja secara individual menurut (Bernadin, 1993 dalam Crimson Sitanggang, 2005) adalah "Kualitas, Kuantitas, Ketepatan Waktu, Efektifitas, Kemandirian dan Komitmen Organisasi."
2. Gaya kepemimpinan

Gaya kepemimpinan merupakan cara pemimpin memanfaatkan kekuatan yang tersedia untuk memimpin para karyawannya. Likret, dalam Handoko, (2012) mengemukakan "Dua kategori gaya dasar ini, orientasi karyawan dan orientasi tugas, menyusun suatu model empat tingkat efektifitas manajemen."

a. Sistem 1, manajer membuat semua keputusan yang berhubungan dengan kerja dan memerintah para bawahan untuk melaksanakannya.

b. Sistem 2, manajer tetap menentukan perintah-perintah, tetapi memberi bawahan kebebasan untuk memberikan komentar terhadap perintahperintah tersebut.

c. Sistem 3, manajer menetapkan tujuan-tujuan dan memberikan perintah-perintah setelah halhal itu didiskusikan terlebih dahulu dengan bawahan.

d. Sistem 4, tujuan-tujuan ditetapkan dan keputusankeputusan kerja dibuat oleh kelompok.

\section{Motivasi}

Malayu S. P. Hasibuan, 2014 dalam Effendy, A.A. (2017), menyatakan Motivasi adalah "Pemberian daya penggerak yang menciptakan kegairahan kerja seseorang, agar mereka mau bekerja sama, bekerja efektif dan terintegrasi dengan segala daya upayanya untuk mencapai kepuasan." Teori motivasi yang paling terkenal adalah hirarki kebutuhan yang diungkapan Abraham Maslow. Hipotesisnya 
mengatakan "Di dalam diri semua manusia bersemayam lima jenjang kebutuhan" (Maslow, dalam Robbins, 2013), yang menjadi indikator yaitu: Fisiologis, Keamanan, Sosial, Penghargaan dan Aktualisasi diri.

4. Disiplin kerja

"Disiplin

merupakan

keadaan ideal dalam mendukung pelaksanaan tugas sesuai aturan dalam rangka mendukung optimalisasi kerja." Adapun indikator dari disiplin kerja adalah (Waridin, 2006 dalam Mohammad, 2005): Kualitas kedisiplinan kerja, Kuantitas pekerjaan, Kompensasi yang diperlukan, Lokasi tempat kerja atau tinggal dan Konservasi

\section{B. Populasi dan Sampel \\ 1. Populasi}

Populasi dalam penelitian ini adalah seluruh karyawan yang ada di perusahaan PT Modernland Realty yang berjumlah 192 karyawan.

\section{Sampel}

Untuk menentukan jumlah sampel, penulis menggunakan rumus Slovin, yaitu Populasi (N) berjumlah 192 karyawan, dengan asumsi tingkat kesalahan $(\mathrm{e})=5 \%$ adalah:

$$
\begin{gathered}
\mathrm{n}=\frac{192}{1+(192)(0,05)^{2}} \\
\mathrm{n}=129,7297 \text { atau 130 orang }
\end{gathered}
$$

\section{Metode Pengumpulan Data}

Metode pengumpulan data yang digunakan dalam penelitian ini adalah: Kuesioner, Observasi dan Studi Pustaka

\section{Metode Analisis Data}

1. Uji Validitas
Uji validitas digunakan untuk "Mengukur sah atau valid tidaknya suatu kuesioner. Suatu kuesioner dikatakan valid jika pertanyaan pada kuesioner mampu untuk mengungkapkan sesuatu yang akan diukur oleh kuesioner tersebut" (Ghozali, 2016).

2. Uji Reliabilitas

Uji reliabilitas merupakan alat untuk "Mengukur suatu kuesioner yang merupakan indikator dari variabel atau konstruk. Suatu kuesioner dikatakan reliable atau handal jika jawaban seseorang terhadap pernyataan adalah konsisten atau stabil dari waktu ke waktu." (Ghozali, 2016). "Suatu konstruk atau variabel dikatakan reliable jika memberikan nilai CronbachAlpha > 0.60." (Nunnally dalam Ghozali, 2016).

3. Uji Asumsi Klasik

Untuk meyakinkan bahwa persamaan garis regresi yang diperoleh adalah linier dan dapat dipergunakan (valid) untuk mencari peramalan, maka akan dilakukan pengujian asumsi multikolinearitas,

heteroskedastisitas, dan normalitas.

4. Analisis Regresi Linier Berganda

Analisis ini digunakan untuk mengetahui seberapa besar pengaruh variabel bebas yaitu: gaya kepemimpinan (X1), motivasi (X2), dan disiplin kerja (X3) terhadap variabel terikatnya yaitu kinerja karyawan (Y). Persamaan regresi linier berganda adalah sebagai berikut (Ghozali, 2016): $Y=a+b 1 X 1+b 2 X 2+$ $\mathrm{b} 3 \mathrm{X} 3+\mathrm{e}$ 
5. Pengujian Hipotesis

a. Uji Signifikansi Simultan (Uji Statistik F)

Dalam penelitian ini, uji $\mathrm{F}$ digunakan untuk "Mengetahui tingkat siginifikansi pengaruh variabel-variabel independen secara bersama-sama (simultan) terhadap variabel dependen." (Ghozali, 2016).

b. Analisis Koefisien Determinasi $\left(\mathrm{R}^{2}\right)$

Koefisien determinasi $\left(\mathrm{R}^{2}\right)$ pada intinya "Mengukur seberapa jauh kemampuan model dalam menerangkan variasi variabel terikat." (Ghozali, 2016). Nilai Koefisien determinasi adalah antara nol dan satu. Nilai $\mathbf{R}^{2}$ yang kecil berarti kemampuan variabel-variabel bebas (gaya kepemimpinan, motivasi dan disiplin kerja) dalam menjelaskan variasi variabel terikat (kinerja karyawan) amat terbatas.

c. Uji Signifikasi Pengaruh Parsial (Uji t)

\section{B. Hasil Penelitian}

\section{Pengujian Validitas}

Tabel 1 Hasil Pengujian Validitas

\begin{tabular}{|c|c|c|c|c|}
\hline NO & Variabel/Indikator & r hitung & r table & Keterangan \\
\hline \multicolumn{5}{|c|}{ Gaya kepemimpinan } \\
\hline 1 & 1 & 0.707 & 0,1723 & Valid \\
\hline 2 & 2 & 0.724 & 0,1723 & Valid \\
\hline 3 & 3 & 0.596 & 0,1723 & Valid \\
\hline 4 & 4 & 0.702 & 0,1723 & Valid \\
\hline \multicolumn{5}{|c|}{ Motivasi } \\
\hline 1 & 1 & 0.466 & 0,1723 & Valid \\
\hline 2 & 2 & 0.558 & 0,1723 & Valid \\
\hline 3 & 3 & 0.779 & 0,1723 & Valid \\
\hline 4 & 4 & 0.575 & 0,1723 & Valid \\
\hline 5 & 5 & 0.779 & 0,1723 & Valid \\
\hline \multicolumn{5}{|c|}{ Disiplin Kerja } \\
\hline 1 & 1 & 0.829 & 0,1723 & Valid \\
\hline 2 & 2 & 0.941 & 0,1723 & Valid \\
\hline
\end{tabular}

\section{HASIL PENELITIAN DAN PEMBAHASAN \\ A. Gambaran Umum Objek}

PT Modernland Realty Tbk merupakan perusahaan yang bergerak pada bidang property di Jakarta. Penelitian ini mengambil sampel karyawan PT Modernland Realty Tbk sebanyak 130 orang dari jumlah populasi 192 karyawan. Sebagai hasil penelitian pendahuluan, berikut ini akan diberikan tinjauan mengenai karakteristik responden yang dinyatakan dalam bentuk tabulasi identitas responden. 


\begin{tabular}{|l|l|l|l|l|}
\hline 3 & 3 & 0.981 & 0,1723 & Valid \\
\hline 4 & 4 & 0.981 & 0,1723 & Valid \\
\hline 5 & 5 & 0.981 & 0,1723 & Valid \\
\hline \multicolumn{4}{|c|}{ Kinerja Karyawan } \\
\hline 1 & 1 & 0.602 & 0,1723 & Valid \\
\hline 2 & 2 & 0.296 & 0,1723 & Valid \\
\hline 3 & 3 & 0.707 & 0,1723 & Valid \\
\hline 4 & 4 & 0.474 & 0,1723 & Valid \\
\hline 5 & 5 & 0.598 & 0,1723 & Valid \\
\hline 6 & 6 & 0.647 & 0,1723 & Valid \\
\hline
\end{tabular}

Tabel tersebut terlihat bahwa korelasi antara masing-masing indikator terhadap total skor konstruk dari setiap variabel menunjukkan hasil yang signifikan, dan menunjukkan bahwa $r$ hitung $>r$ tabel. Sehingga dapat disimpulkan bahwa semua item pertanyaan dinyatakan valid.

\section{Pengujian Reliabilitas}

Tabel 2 Hasil Pengujian Reliabilitas

\begin{tabular}{|l|c|c|}
\hline \multicolumn{1}{|c|}{ Variabel } & Alpha & Keterangan \\
\hline $\begin{array}{l}\text { Gaya } \\
\text { Kepemimpinan }\end{array}$ & 0,78 & Reliabel \\
\hline Motivasi & 0,741 & Reliabel \\
\hline Disiplin Kerja & 0,833 & Reliabel \\
\hline $\begin{array}{l}\text { Kinerja } \\
\text { Karyawan }\end{array}$ & 0,707 & Reliabel \\
\hline
\end{tabular}

Hasil uji reliabilitas tersebut menunjukkan bahwa semua variabel mempunyai koefisien Alpha yang cukup besar yaitu diatas 0,60 sehingga dapat dikatakan semua konsep pengukur masing-masing variabel dari kuesioner adalah reliabel sehingga untuk selanjutnya item-item pada masing-masing konsep variabel tersebut layak digunakan sebagai alat ukur.

\section{Uji Asumsi Klasik}

\section{a. Uji Normalitas}

Uji normalitas adalah pengujian tentang kenormalan distribusi data. Jika data menyebar di sekitar garis diagonal dan mengikuti arah garis diagonal atau grafik histogramnya menunjukkan pola distribusi normal, maka model regresi memenuhi asumsi normalitas.

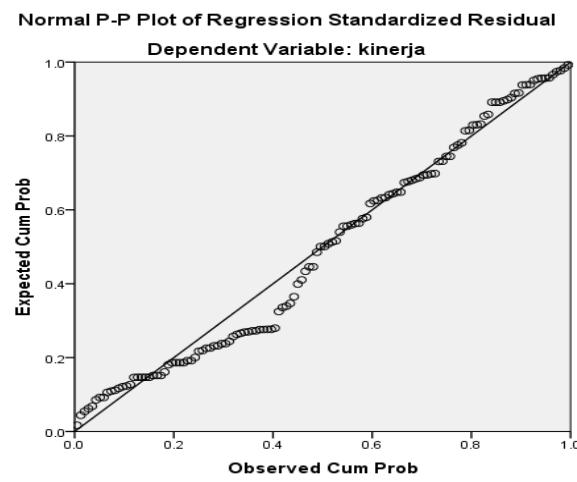

\section{Gambar 2 : Uji Normalitas}

Dapat dilihat dari grafik diatas bahwa titik - titik menyebar disekitar garis dan mengikuti garis diagonal, dapat diartikan bahwa nilai residual yang dihasilkan dari regressi tersebut normal.

\section{b. Uji Multikolinearitas}

Pengujian ada tidaknya gejala multikolinieritas dilakukan dengan mempertahankan nilai matriks korelasi yang dihasilkan pada saat pengolahan data serta nilai VIF (Variance Inflation Factor) dan tolerance sebagai berikut: 
Tabel 3 Uji Multikolinearitas

\begin{tabular}{|l|r|l|}
\hline \multirow{2}{*}{ Model } & \multicolumn{2}{|l|}{$\begin{array}{l}\text { Collinearity } \\
\text { Statistics }\end{array}$} \\
\cline { 2 - 4 } & \multicolumn{1}{|l|}{ Tolerance } & VIF \\
\hline 1 (Constant) & & \\
Gaya &, 418 & 2,394 \\
Kepemimpinan & & \\
Motivasi &, 411 & 2,431 \\
Disiplin Kerja &, 976 & 1,024 \\
\hline
\end{tabular}

a. Dependent Variable: (Y) Kinerja

Karyawan

Dari hasil output data didapatkan bahwa nilai VIF < 10,00 dan nilai tolerance $>0,10$ maka tidak terjadi gejala multikolineritas.

\section{c. Uji Heteroskedastisitas}

Pengujian

Heteroskedastisitas ini digunakan untuk melihat apakah variabel pengganggu mempunyai varian yang sama atau tidak.

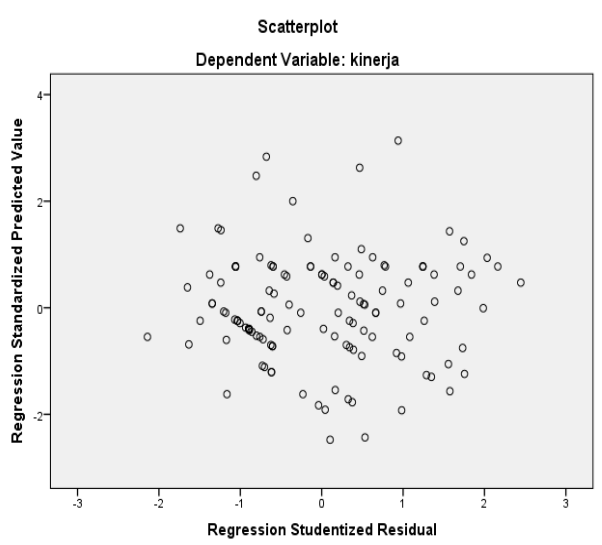

Gambar 3 : Uji

\section{Heteroskedastisitas}

Dari output di atas dapat diketahui bahwa titik-titik tidak membentuk pola yang jelas, dan titik-titik menyebar di atas dan di bawah angka 0 pada sumbu Y. Jadi dapat disimpulkan bahwa tidak terjadi masalah heteroskedastisitas dalam model regresi.

\section{Analisis Persamaan Regresi Linear Berganda}

Tabel 4 : Hasil Estimasi Regresi

Coefficients

\begin{tabular}{|c|c|c|c|c|c|c|c|}
\hline \multirow{2}{*}{ Model } & \multicolumn{2}{|c|}{$\begin{array}{c}\text { Unstandardized } \\
\text { Coefficients }\end{array}$} & $\begin{array}{c}\text { Standardized } \\
\text { Coefficients }\end{array}$ & \multirow{2}{*}{$\mathrm{T}$} & \multirow{2}{*}{$\begin{array}{c}\text { Sig } \\
\cdot\end{array}$} & \multicolumn{2}{|c|}{$\begin{array}{c}\text { Collinearity } \\
\text { Statistics }\end{array}$} \\
\cline { 2 - 4 } & $\mathrm{B}$ & Std. Error & Beta & & Tolerance & VIF \\
\hline 1 (Constant) & .841 & 2.053 & & .410 & $\begin{array}{c}.68 \\
3\end{array}$ & & \\
\hline Motivasi & .303 & .137 & .223 & $\begin{array}{c}2.20 \\
7\end{array}$ & $\begin{array}{c}.02 \\
9\end{array}$ & .418 & $\begin{array}{c}2.39 \\
4\end{array}$ \\
\hline $\begin{array}{c}\text { Gaya } \\
\begin{array}{c}\text { Kepemimpi } \\
\text { nan }\end{array}\end{array}$ & .718 & .159 & .461 & $\begin{array}{c}4.52 \\
7\end{array}$ & $\begin{array}{c}.00 \\
0\end{array}$ & .411 & $\begin{array}{c}.2 .43 \\
1\end{array}$ \\
\hline $\begin{array}{c}\text { Disiplin } \\
\text { Kerja }\end{array}$ & .130 & .063 & .137 & $\begin{array}{c}2.06 \\
7\end{array}$ & $\begin{array}{c}.04 \\
1\end{array}$ & .976 & 1024 \\
\hline
\end{tabular}

a. Dependent Variable: Kinerja Karyawan

Dari persamaan tersebut dapat dijelaskan bahwa:

a. Variabel gaya kepemimpinan, motivasi dan disiplin kerja mempunyai arah koefisien yang bertanda positif terhadap kinerja karyawan.

b. Koefisien gaya kepemimpinan memberikan nilai sebesar 0,461 yang berarti bahwa jika gaya 
kepemimpinan semakin baik dengan asumsi variabel lain tetap maka kinerja karyawan akan mengalami peningkatan.

c. Koefisien motivasi memberikan nilai sebesar 0,223 yang berarti bahwa jika motivasi kerja semakin tinggi dengan asumsi variabel lain tetap maka kinerja karyawan akan mengalami peningkatan.

d. Koefisien disiplin kerja memberikan nilai sebesar 0,137 yang berarti bahwa jika disiplijn kerja semakin kuat dengan asumsi variabel lain tetap maka kinerja karyawan akan mengalami peningkatan.

\section{Koefisien Korelasi Berganda dan Determinasi $\left(\mathbf{R}^{2}\right)$}

Tabel 5 Koefisien determinasi Model Summary

\begin{tabular}{|c|c|c|c|c|}
\hline Model & $\mathrm{R}$ & $\begin{array}{c}\mathrm{R} \\
\text { Square }\end{array}$ & $\begin{array}{c}\text { Adjusted } \\
\mathrm{R} \\
\text { Square }\end{array}$ & $\begin{array}{c}\text { Std. } \\
\text { Error of } \\
\text { the } \\
\text { Estimate }\end{array}$ \\
\hline 1 & $.679^{\mathrm{a}}$ & .462 & .449 & 219.007 \\
\hline
\end{tabular}

a. Predictors: (Constant), Disiplin Kerja, Gaya Kepemimpinan, Motivasi

Hasil perhitungan korelasi berganda didapat 0,679 maka dinyatakan memiliki hubungan yang kuat antara ketiga variabel bebas terhadap variabel terikat dan hasil koefisien determinasi yang diperoleh sebesar 0,462. Hal ini berarti $46,2 \%$ variasi variabel kinerja karyawan dapat dijelaskan oleh variabel gaya kepemimpinan, motivasi dan disiplin kerja, sedangkan sisanya sebesar 53,8\% diterangkan oleh variabel lain yang tidak diajukan dalam penelitian ini.

\section{Uji t (Uji Hipotesis Secara Parsial)}

Tabel 6 Hasil Uji t Secara Parsial

\begin{tabular}{|c|c|c|}
\hline Variabel Bebas & $\begin{array}{c}\mathrm{t} \\
\text { hitung }\end{array}$ & Sig. $\mathrm{t}$ \\
\hline $\begin{array}{c}\text { Gaya } \\
\text { Kepemimpinan } \\
\text { (X1) }\end{array}$ & 4.527 & 0.000 \\
\hline Motivasi (X2) & 2.207 & 0.029 \\
\hline $\begin{array}{c}\text { Disiplin Kerja } \\
(\mathrm{X} 3)\end{array}$ & 2.067 & 0.041 \\
\hline
\end{tabular}

a. Uji Hipotesis 1 (H1)

Dari tabel tersebut terlihat bahwa hasil pengujian hipotesis gaya kepemimpinan menunjukkan nilai $\mathrm{t}$ hitung sebesar 4,527 dengan taraf signifikansi 0,000 . Taraf signifikansi tersebut lebih kecil dari 0,05 , yang berarti bahwa hipotesis dalam penelitian ini menolak Ho dan menerima Ha. Dengan demikian dapat berarti bahwa hipotesis H1 "Gaya Kepemimpinan mempunyai pengaruh positif terhadap Kinerja karyawan "diterima.

b. Uji Hipotesis 2 (H2)

Dari tabel tersebut terlihat bahwa hasil pengujian hipotesis motivasi menunjukkan nilai $\mathrm{t}$ hitung sebesar 2,207 dengan taraf signifikansi 0,029. Taraf signifikansi tersebut lebih kecil dari 0,05 , yang berarti bahwa hipotesis dalam penelitian ini menerima $\mathrm{Ha}$ dan menolak Ho. Dengan 
demikian dapat berarti bahwa hipotesis $\mathrm{H} 2$ "Motivasi berpengaruh positif terhadap Kinerja karyawan "diterima.

c. Uji Hipotesis 3 (H3)

Dari tabel tersebut terlihat bahwa hasil pengujian hipotesis disiplin kerja menunjukkan nilai $\mathrm{t}$ hitung sebesar 2,067 dengan taraf signifikansi 0,041 . Taraf signifikansi tersebut lebih kecil dari 0,05 , yang berarti bahwa hipotesis dalam penelitian ini menolak Ho dan menerima Ha. Dengan demikian berarti bahwa hipotesis H3 "Disiplin kerja mempunyai pengaruh po sitif terhadap Kinerja karyawan "diterima.

\section{Uji F (Pengujian hipotesis secara simultan)}

Tabel 7 Hasil analisis regresi secara simultan ANOVA

\begin{tabular}{|c|c|c|c|c|c|}
\hline Model & $\begin{array}{c}\text { Sum of } \\
\text { Squares }\end{array}$ & Df & $\begin{array}{c}\text { Mean } \\
\text { Square }\end{array}$ & F & Sig. \\
\hline Regression & 518.275 & 3 & 172.758 & 36.018 & $.000^{\mathrm{b}}$ \\
\hline Residual & 604.348 & 126 & 4.796 & & \\
\hline Total & 1.122 .623 & 129 & & & \\
\hline
\end{tabular}

a. Predictors: (Constant), Disiplin Kerja, Gaya Kepemimpinan, Motivasi b. Dependent Variable: Kinerja Karyawan

Pengujian pengaruh variabel bebas secara bersamasama terhadap variabel terikatnya dilakukan dengan menggunakan uji F. Hasil perhitungan statistik menunjukkan nilai $\mathrm{F}$ hitung $=$
36.018. Dengan menggunakan batas signifikansi 0,05 , maka diperoleh nilai signifikansi tersebut lebih kecil dari 0,05. Hal ini berarti bahwa hipotesis yang menyatakan bahwa secara simultan variabel gaya kepemimpinan, motivasi dan disiplin kerja mempunyai pengaruh terhadap kinerja karyawan.

\section{KESIMPULAN DAN SARAN}

\section{A. Kesimpulan}

Dari pembahasan yang telah diuraikan, maka dapat ditarik kesimpulan sebagai berikut:

1. Hasil pengujian hipotesis telah membuktikan terdapat pengaruh antara gaya kepemimpinan dengan kinerja karyawan. Pengujian membuktikan bahwa gaya Kepemimpinan memiliki pengaruh positif terhadap kinerja karyawan. Dilihat dari perhitungan yang telah dilakukan diperoleh nilai koefisien sebesar 0,461 dan nilai $\mathrm{t}$ hitung sebesar 4,527 dengan nilai signifikansi sebesar 0,000 tersebut lebih kecil dari 0,05 dengan demikian Ha diterima dan Ho ditolak. Hal ini mendukung penelitian yang dilakukan oleh penelitian menurut Rosari (2005) bahwa gaya kepemimpinan pada dasarnya menekankan untuk menghargai tujuan individu sehingga nantinya para individu akan memiliki keyakinan bahwa kinerja aktual akan melampaui harapan kinerja mereka. 
2. Hasil pengujian hipotesis telah membuktikan terdapat pengaruh antara motivasi dengan kinerja karyawan. Pengujian membuktikan bahwa motivasi memiliki pengaruh positif terhadap kinerja karyawan. Dilihat dari perhitungan yang telah dilakukan diperoleh nilai koefisien sebesar 0,223 dan nilai $\mathrm{t}$ hitung sebesar 2,207 dengan taraf signifikansi hasil sebesar 0,029 tersebut lebih kecil dari 0,05 , yang berarti bahwa hipotesis dalam penelitian ini menerima $\mathrm{Ha}$ dan menolak Ho. Hal ini mendukung penelitian yang dilakukan oleh penelitian Suharto dan Budi Cahyono (2005) mengemukakan bahwa salah satu faktor yang mempengaruhi kinerja adalah motivasi pekerja.

3. Hasil pengujian hipotesis telah membuktikan terdapat pengaruh antara disiplin kerja dengan kinerja karyawan. Pengujian membuktikan bahwa disiplin kerja memiliki pengaruh positif terhadap kinerja karyawan. Dilihat dari perhitungan yang telah dilakukan diperoleh nilai koefisien sebesar 0,137 dan nilai t hitung 2,067 dengan taraf signifikansi hitung sebesar 0,041 tersebut lebih kecil dari 0,05 , yang berarti bahwa hipotesis dalam penelitian ini menolak Ho dan menerima Ha. Hal ini mendukung penelitian yang dilakukan oleh Budi Setiyawan dan Waridin (2006) yang mengungkapkan bahwa disiplin kerja karyawan bagian dari faktor kinerja.

4. Hasil pengujian hipotesis telah membuktikan terdapat pengaruh antara gaya kepemimpinan, motivasi dan disiplin kerja secara simultan terhadap kinerja karyawan. Pengujian membuktikan bahwa disiplin kerja memiliki pengaruh positif terhadap kinerja karyawan. Dilihat dari perhitungan yang telah dilakukan diperoleh nilai $\mathrm{F}$ hitung $=36.018$. Dengan menggunakan batas signifikansi 0,05 , maka diperoleh nilai signifikansi tersebut lebih kecil dari 0,05 . Hal ini berarti bahwa hipotesis yang menyatakan bahwa secara simultan variabel gaya kepemimpinan, motivasi dan disiplin kerja mempunyai pengaruh terhadap kinerja karyawan.

\section{B. Saran}

Berdasarkan kesimpulan yang telah dilakukan maka saran yang dapat diberikan dalam penelitian ini yaitu:

1. Bagi Perusahaan

Hendaknya perusahaan dalam meningkatkan kinerja karyawan lebih menitikberatkan pada motivasi karyawan, dilihat dari kuesioner yang telah diisi oleh karyawan PT Modernland Realty Tbk tersebut diperoleh data bahwa karyawan memiliki motivasi yang tinggi pada pekerjaan yang mereka laksanakan, sehingga dengan perusahaan lebih memotivasi 
karyawannya misalnya dengan pemberian penghargaan terhadap karyawan yang berprestasi atau kenaikan jabatan akan dapat meningkatkan kinerja karyawan yang lebih baik lagi.

2. Bagi Penelitian Selanjutnya

Hasil Uji $\mathrm{R}^{2}$ menunjukkan masih ada variabel-variabel lain yang harus diperhatikan dalam penelitian ini. Penelitianpenelitian lebih lanjut, hendaknya menambah variabel lain yang dapat mempengaruhi kinerja karyawan, karena dengan semakin baik kinerja dari karyawan maka akan berpengaruh baik juga bagi perusahaan.

\section{DAFTAR PUSTAKA}

Aritonang, Keke.T. 2005. Kompensasi Kerja, Disiplin Kerja Guru Dan Kinerja Gutu SMP Kristen BPK PENABUR. Jurnal Pendidikan Penabur. No 4. Th IV. Jakarta.

Crimson, Sitanggang, 2005, Analisis Pengaruh Prilaku Pemimpin Terhadap KinerjaPegawai Pada Sekretariat Kotamadya Jak-Bar. Skripsi, UNDIP Semarang.

Effendy, A. A. (2017). Analisis

Pengaruh Peran Kepemimpinan

Dan Budaya Organisasi

Terhadap Motivasi Kerja Yang Berdampak Pada Peningkatan Kinerja Karyawan (Studi Kasus PT. Putra Cita Nusa). Inovasi, 4(1).

Effendy, A. A., \& Fadhilah, A. (2018). Pengaruh Insentif Dan Motivasi Terhadap Kinerja Karyawan Pada PT. Calibramed Jakarta Selatan. JIMF (Jurnal
Ilmiah Manajemen

Forkamma), 1(3).

Ghozali, Imam. 2016. Aplikasi

Analisis Multivariate

dengan Program IBM SPSS 23

(Edisi 8). Cetakan ke VIII, Semarang: BP Universitas Diponegoro. Semarang.

Guritno, Bambang dan Waridin.

2005. Pengaruh Persepsi

Karyawan Mengenai Perilaku

Kepemimpinan, Kepuasan

Kerja Dan Motivasi Terhadap

Kinerja. JRBI.Vol 1. No 1.

Hal: 63-74.

Hakim, Abdul. 2006. Analisis

Pengaruh Motivasi, Komitmen

Organisasi Dan Iklim

Organisasi Terhadap Kinerja

Pegawai Pada Dinas

Perhubungan Dan

Telekomunikasi Provinsi Jawa

Tengah. JRBI.Vol 2. No 2.

Hal: 165-180.

Handoko, T. Hani. 2012. Manajemen.

Edisi 2. BPFE. Yogyakarta.

Hasibuan, Malayu. 2018.

Manajemen Sumber Daya

Manusia.PT. Bumi

Aksara.Jakarta.

Masrukhin dan Waridin. 2004.

Pengaruh Motivasi Kerja,

Kepuasan Kerja, Budaya

Organisasi Dan

Kepemimpinan Terhadap

Kinerja Pegawai. EKOBIS.Vol

7. No 2. Hal: 197-209.

Rosari, Reni. 2005. Analisis Gaya

Kepemimpinan Dosen-Dosen

Di Fakultas Ekonomi UGM

Yogyakarta.Jurnal Telaah

Bisnis. Vol 6. No 1. Hal: 87-

109.

Robbins. 2013. Manajemen Sumber

Daya Manusia, PT. Sinar Abadi, Jakarta 
Rialmi, Z., \& Morsen, M. (2020). Pengaruh Komunikasi Terhadap Kinerja Karyawan PT Utama Metal Abadi. JENIUS, 3(2), 221-227.

Rialmi, Z. (2017). Pengaruh Keadilan Prosedural Yang Diterapkan Kepemimpinan Pegawai Dan Kepuasan Kerja Pegawai Terhadap Kinerja Dari Pegawai BPBD Provinsi Riau. Jurnal Mandiri: Ilmu Pengetahuan, Seni, dan Teknologi, 1(2), 353-374.

Rivai, Veithzal. 2014. Manajemen Sumber Daya Manusia Untuk Perusahaan. PT. Rajagrafindo Persada. Jakarta.

Rivai, Veithzal dan Basri. 2014. Performance Appraisal: Sistem Yang Tepat UntukMenilai Kinerja Karyawan Dan Meningkatkan Daya Saing Perusahaan. PT. Rajagrafindo Persada. Jakarta.

Sekaran, Uma. 2006. Research Methode For Business: Metodologi Penelitian Untukbisnis. Salemba Empat. Jakarta.

Setiyawan, Budi dan Waridin.2006. Pengaruh Disiplin Kerja Karyawan Dan Budaya Organisasi Terhadap Kinerja Di Divisi Radiologi RSUP Dokter Kariadi Semarang. JRBIVol 2. No 2. Hal: 181-198.

Sugiyono. 2016 "Metode Penelitian Kuantitatif, Kualitatif, dan
R\&D”. Cetaka ke-23 CV. Alfabeta. Bandung.

Sunarsi, D. (2020). Panduan Meningkatkan Kinerja Dan Kepuasan Guru. Kota Serang: Desanta Muliavisitama

Sunarsi, D. (2019). Seminar Sumber Daya Manusia. Tangerang Selatan: Unpam Press

Sunarsi, D. (2018). Buku Ajar: Seminar Perencanaan Sumber Daya Manusia. Tangerang Selatan: Asmoro Mediatama

Sunarsi, D., \& Yuliani, I. (2019). Pengaruh Gaya Kepe Mimpinan Dan Budaya Organisasi Terhadap Kinerja Karyawan Pada Bank BTN Kantor Cabang Tangerang. Jurnal Semarak, 2(1).

Suranta, Sri. 2002. Dampak Motivasi Karyawan Pada Hubungan Antara Gaya Kepemimpinan Dengan Kinerja Karyawan Perusahaan BisnisEmpirika.Vol 15. No 2. Hal: 116-138.

Tampubolon, Biatna. D. 2007. Analisis Faktor Gaya Kepemimpinan Dan Faktor Etos Kerja Terhadap Kinerja Pegawai Pada Organisasi Yang Telah Menerapkan SNI 199001-2001. Jurnal Standardisasi. No 9. Hal: 106115.

Tika, P. 2014. Budaya Organisasi

Dan Peningkatan Kinerja Perusahaan.PT Bumi Aksara. Jakarta. 